\title{
France considers law regulating the human body
}

PARIS-One year later-and with a new administration - the French government is set to relaunch legislation that would give the country perhaps the world's most comprehensive law regulating the rights of the human body. In November 1992, the Socialist government first introduced the so-called bioethics bill in the French parliament. The bill encompassed such areas as in vitro fertilization, embryo technology, and surrogate motherhood, as well as concerns closer to biotechnology, like gene therapy, prenatal screening, and the patenting of human DNA sequences. The bill, though, was not passed before the elections in March swept the Socialists from power.

It is important for France to pass the legislation, according to JeanFrancois Mattei, a member of the parliament who is reexamining the bill for the current Conservative prime minister, Edouard Balladur. "It would take too long to elaborate a new bill," says Mattei. "There is an urgency in having regulations in fields like artificial reproduction techniques, prenatal genetic screening, genetic identification tests, and gene therapy." Noelle Lenoir, a member of the French Conseil Constitutional (Paris) who in 1991 prepared a report for the Socialist government on bioethics, is also convinced of the need for swift action. "Now that medicine is not only a therapeutic service but also a social service-since it deals with problems like motherhood and organ donation-and now that industry and ethics are more closely linked together, especially in biotechnology, the law must address these issue clearly," says Lenoir.

The adoption of the bill would restrict gene therapy and prenatal screening. Though somatic gene therapy will be subject to the same approval processes as conventional therapeutic approaches, germline gene therapy will be banned completely. As for prenatal screening, the expectation is that, under a Conservative government, parliament "will only allow prenatal testing that is medically justifiable," predicts Mattei.
With regards to ownership of the human body, the bill affirms that human genomes, human genes, or partial human cDNA sequences are not patentable. Intellectual property protection is available only when a gene sequence is used in an industrial process-as part of a recombinant organism, for instance-when the process and its products may be patentable.

Yet arguments concerning the bioethics bill will not be based entirely on science. Axel Khan, a member of the government's National Ethics Committee, is concerned that, when the bill is discussed in parliament, decisions will be made more on the basis of ideological pressure than rational analysis. Nevertheless, Khan stresses that the bill will be extremely important in reaffirming the dignity of the human body in the face of advancing technology. "France will stimulate debate worldwide by establishing strong principles on ethical issues," he says.

-Angiola Bono

Angiola Bono is a freelance writer working in Paris and Milan.
The law

encompasses

such areas as

gene therapy

and the

patenting of

human DNA

sequences.

\section{Finland considering far-reaching biotech rules}

HELSINKI-A new far-reaching law to regulate all aspects of Finnish biotechnology-including medical, agricultural, environmental, and industrial applicationshas been drafted by a special working group appointed by the Finnish Parliament. The so-called Biotechnology Working Committee (BWC) recently presented its first draft of the new law to the Ministry of the Environment (Helsinki). The eventual law will likely not conflict with European Community (EC, Brussels) policy on biotechnology. Though Finland is not an EC member, it is presently applying for such membership.

The BWC noted that Finland has 70 organizations - both public and private-actively pursuing biotechnology. Their main focus is on plant and animal research, with the main players being the wood-processing, waste-disposal, and food industries. An increasing number of medical-biotech firms are being established, however, particularly in the areas of hereditary disease and vaccines.

The BWC has recommended establishing a permanent Gene Technology Authority (GTA), a supervisory board that would operate as an independent body within the Ministry of Health and Social Welfare (Helsinki). The GTA would have broad powers of supervision to make biotech organizations accountable for their actions. Each organization conducting biotechnology research would have to inform the GTA of all ongoing and planned activities. The GTA would assess this research, as well as its impact on society and nature.

The BWC proposes two levels of regulation for biotechnology experimentation and production. The aim is to make it easier for organizations to conduct "legitimate" research projects, while curtailing them from conducting "ambiguous" projects. For level I activities, organizations will need to notify authorities of their work, but authority approval of new projects or changes to existing projects will be virtually automatic. Public hearings for level I activities will not be necessary.

For level II activities, public hearings will be held in the event that the activities involve installations that require approval under emissioncontrol laws. Ideally, the waiting period between organization notification and authority approval will be three months.

The BWC proposal calls for a central register of all level $I$ and level II activities. After the proposal receives input from interest groups, however, the betting is that the register will contain only level II activities.

The BWC proposal has a good chance of become law by the beginning of 1995. "Drafting a law of this type is difficult, because there are numerous risks involved. It may turn out differently than first expected,' says Erkki Hollo, the BWC's chairman.

_ Gerard O'Dwyer
The aim is to

make it

easier for

"legitimate"

research

projects. 